\title{
Molecular Screening of Blast Resistance Genes in Rice using SSR Markers
}

\author{
A. K. Singh ${ }^{1 *}$, P. K. Singh ${ }^{1}$, Madhuri Arya ${ }^{1}$, N. K. Singh ${ }^{2}$ and U. S. Singh ${ }^{3}$ \\ ${ }^{I}$ Department of Genetics and Plant Breeding, Institute of Agricultural Sciences, Banaras Hindu University, Varanasi-221005, \\ India \\ ${ }^{2}$ National Research Centre on Plant Biotechnology, Indian Agricultural Research Institute, New Delhi 110012 , India \\ ${ }^{3}$ STRASA-IRRI-India Office, Rajendra Place, $9^{\text {th }}$ Floor, Aggrawal Corporate Tower, New Delhi 110008 , India
}

(Received on June 12, 2014; Revised on December 9, 2014; Accepted on November 17, 2014)

Rice Blast is the most devastating disease causing major yield losses in every year worldwide. It had been proved that using resistant rice varieties would be the most effective way to control this disease. Molecular screening and genetic diversities of major rice blast resistance genes were determined in 192 rice germplasm accessions using simple sequence repeat (SSR) markers. The genetic frequencies of the $\mathbf{1 0}$ major rice blast resistance genes varied from $19.79 \%$ to $54.69 \%$. Seven accessions IC337593, IC346002, IC346004, IC346813, IC356117, IC356422 and IC383441 had maximum eight blast resistance gene, while FR13B, Hourakani, Kala Rata 1-24, Lemont, Brown Gora, IR87756-20-2-23, IC282418, IC356419, PKSLGR-1 and PKSLGR-39 had seven blast resistance genes. Twenty accessions possessed six genes, 36 accessions had five genes, 41 accessions had four genes, 38 accessions had three genes, 26 accessions had two genes, 13 accessions had single $\boldsymbol{R}$ gene and only one accession IC438644 does not possess any one blast resistant gene. Out of 192 accessions only 17 accessions harboured 7 to 8 blast resistance genes.

Keywords : blast, marker assisted selection, resistance genes, rice, SSR markers

Rice blast is one of the most destructive diseases affecting rice production worldwide, which caused an economic loss up to $65 \%$ yield in susceptible cultivars (Li et al., 2007). Losses are dependent on the growth stage of the plant at which infection occurs, level of resistance and prevailing environmental conditions. It occurs more frequently in rainfed areas in wet season due to favourable environmental

*Corresponding author.

Phone) +91-9451173551, FAX) +91-5422369971

E-mail)anilbhu987@gmail.com conditions for disease development. The identification and isolation of additional host blast resistance $(\mathrm{R})$ genes and pathogen avirulence gene are now required to deepen understanding of molecular mechanisms involved in the hostpathogen interaction (Valent, 1990). Generally R genes are identified in land races, cultivars and wild rice collections using differential physiological races of Magnaporthe oryzae (Tanksley et al., 1997). With fine mapping and cloning of many blast resistance genes, many PCR-based markers have been developed to screen and identify different blast resistance genes. DNA markers closely linked to a blast $\mathrm{R}$ gene that confers resistance to a particular race of the pathogen can be effectively employed for marker assisted selection (MAS), which is much faster than traditional pathogenicity assays. Accurate identification of a particular $\mathrm{R}$ gene in diverse elite germplasm using DNA markers and differential blast races is an essential step for ensuring the accuracy of $\mathrm{R}$ gene utilization in using MAS for different rice breeding programs (Roy-Chowdhury et al., 2012a).

Recently, more than 100 major blast resistance genes from japonica (45\%), indica (51\%) and other (4\%) genotypes have been identified and documented (Ballini et al., 2008; Berruyer et al., 2003; Chauhan et al., 2002; Chen et al., 2002; Huang et al., 2010; Liu et al., 2004; Liu et al., 2005; Sharma et al., 2012; Xiao et al., 2010; Zhu et al., 2004); and many rice varieties with complete resistance to $M$. grisea have been developed, but in many cases this resistance has been breakdown within a few years of the initial cultivation owing to the emergence of stronger virulent isolates of rice blast fungus (Han et al., 2001). Partial and field resistance of rice blast has received much attention as a means of effective control of a parasite under natural field condition and conferring durable blast resistance when exposed to new races of that parasite (Hittalmani et al., 2000; Liu et al., 2005). These $\mathrm{R}$ genes are distributed throughout the 12 rice chromosomes except chromosome 3 (Liu et al., 2010; Yang et al., 2008). Out of them, 22 have been 
Table 1. List of blast resistance genes, markers and germplasm used as check variety

\begin{tabular}{llllllllll}
\hline \multirow{2}{*}{ S.No. Gene } & $\begin{array}{l}\text { Chromo- } \\
\text { some locus }\end{array}$ & $\begin{array}{l}\text { Check } \\
\text { variety }\end{array}$ & $\begin{array}{l}\text { Linked } \\
\text { marker }\end{array}$ & $\begin{array}{l}\text { Linkage } \\
\text { distance } \\
(\mathrm{cM})\end{array}$ & $\begin{array}{l}\text { Expected PCR } \\
\text { product size } \\
(\mathrm{bp})\end{array}$ & SSR mottif & $\begin{array}{l}\text { Annealing } \\
\text { temp. }\left({ }^{\circ} \mathrm{C}\right)\end{array}$ & References \\
\hline 1 & Pi-9 & 6 & PB-1460 & RM 541 & 0.6 & 158 & (TC)16 & 55 & Cho et al., 2008 \\
2 & Pi-1 & 11 & PB-1460 & RM 224 & 0.0 & 157 & (AAG)8(AG)13 & 56.4 & Fuentes et al., 2007 \\
3 & Pi5-(t) & 11 & PB-1460 & RM 21 & 0.0 & 157 & (GA)18 & 60.40 & Cuong et al., 2006 \\
4 & Piz-5 & 6 & PB-1460 & RM 527 & 0.3 & 233 & (GA)17 & 55 & Fjellstrom et al., 2006 \\
5 & Pi-b & 2 & PB-1460 & RM 208 & 1.2 & 173 & (CT)17 & 57.85 & Hayashi et al., 2006 \\
6 & Pi-ta & 12 & PB-1460 & RM 247 & 5.0 & 131 & (CT)16 & 55.25 & Eizenga et al., 2006 \\
7 & Pi33 & 8 & IR-64 & RM 72 & 11.5 & 166 & (TAT)5C(ATT)15 56.95 & Berruyer et al., 2003 \\
8 & Pi-27(t) & 1 & IR-64 & RM 259 & 9.7 & 162 & (CT)17 & 56.65 & Zhu et al., 2004 \\
9 & Pitp(t) & 1 & Tetep & RM 246 & 0.0 & 116 & (CT)20 & 58.50 & Barman et al., 2004 \\
10 & Pi-k ${ }^{\mathrm{h}}$ & 11 & Tetep & RM 206 & 0.6 & 147 & (CT)21 & 56.30 & Sharma et al., 2005 \\
\hline
\end{tabular}

cloned namely Pib, Pita, Pik-h, Pi9, Pi2, Piz-t, Pid2, Pi36, Pi37, Pik-m, Pit, Pi5, Pid3, pi21, Pb1, Pish, Pik, Pik-p, Pia, NLS1, Pi25 and Pi54rh (Ashikawa et al., 2008; Bryan et al., 2000; Chen et al., 2006; Chen et al., 2011; Das et al., 2012; Fukuoka et al., 2009; Hayashi et al., 2010; Hayashi and Yoshida, 2009; Lin et al., 2007; Lee et al., 2009; Liu et al., 2007; Okuyama et al., 2011; Qu et al., 2006; Sharma et al., 2005; Shang et al., 2009; Takahashi et al., 2010; Tang et al., 2011; Wang et al., 1999; Yuan et al., 2011; Zhou et al., 2006; Zhai et al., 2011). However, it is imperative to identify broad-spectrum blast resistance genes for effective protection against dynamic blast isolates of $M$. grisea. Highly adaptive virulent isolates/races of the pathogen often challenge the effectiveness of deployed $\mathrm{R}$ genes and thus urge the need for the positive screening and identification of different blast $\mathrm{R}$ genes in the germplasm collection (Wang et al., 2010).

The identification and isolation of additional host resistance genes and pathogen avirulence genes is now required to deepen understanding of molecular mechanisms involved in the host-pathogen interaction and strategic deployment of resistance genes in commercial cultivars. Molecular markers are now widely used to characterize gene bank collections that contain untapped resources of distinct alleles which will remain hidden unless efforts are initiated to screen them for their potential use and function. Thus, this study was carried out to acquire the information for genetic diversities of blast resistance genes in rice germplasm accessions, so that efforts can be utilized to develop high yielding rice cultivars with resistance to blast through markers assisted selection.

\section{Materials and Methods}

Plant materials. The experimental materials comprised of 192 rice germplasm accessions received from Networking Project National Research Centre on Plant Biotechnology, New Delhi, Birsa Agricultural University, Ranchi and Department of Genetics and Plant Breeding, Institute of Agricultural Sciences, Banaras Hindu Varanasi, India, and their seeds were multiplied in wet season 2013. The details of the source of 192 rice accessions are presented in Table 2.

DNA extraction. Young leaves were collected from two week old plantlets of each germplasm grown in the plant growth chamber. The $40 \mathrm{mg}$ leaves were taken from each accession placed in $1.2 \mathrm{ml}$ collection microtubes (Qiagen Tissue Lyser II, Qiagen, U.S.A.) and in each microtube 3 $\mathrm{mm}$ tungsten beads were dispensed by bead dispenser and kept at $-80^{\circ} \mathrm{C}$ for $4 \mathrm{hrs}$. Tissues were disrupted and homogenized by qiagen tissue lyser to a fine powder at frequency of 30 vibrations/seconds for 30 seconds. Fine powdered leaf samples were used for isolation of genomic DNA using CTAB (hexadecyl trimethyl ammonium bromide) method (Doyle and Doyle, 1987). The DNA was quantified spectrophotometrically (Perkin Elmer, Singapore) by measuring A260/A280, and DNA quality was checked by electrophoresis in $0.8 \%$ agarose gel.

SSR analysis. Ten previously reported SSR markers synthesized by Eurofins Genomics (Bangalore, India), were used to analyze the status of the blast resistance genes (Table 1). The amplification was carried out in $15 \mu \mathrm{l}$ of reaction 
Table 2. List of one hundred ninety two rice germplasm accessions, their source and genotypic screening for blast resistance gene with SSR markers

\begin{tabular}{|c|c|c|c|c|c|c|c|c|c|c|c|c|c|}
\hline \multirow[b]{2}{*}{ S.No. } & \multirow[b]{2}{*}{ Accession Number } & \multirow[b]{2}{*}{ Source } & \multicolumn{11}{|c|}{ Blast resistance genes } \\
\hline & & & $\begin{array}{l}P i z-5 \\
(\mathrm{RM} \\
527)\end{array}$ & $\begin{array}{l}P i-9 \\
(\mathrm{RM} \\
541)\end{array}$ & $\begin{array}{c}\text { Pitp(t) } \\
\text { (RM } \\
246)\end{array}$ & $\begin{array}{l}P i-1 \\
(\mathrm{RM} \\
224)\end{array}$ & $\begin{array}{c}P i-5(t) \\
(\mathrm{RM} \\
21)\end{array}$ & $\begin{array}{c}P i-33 \\
(\mathrm{RM} \\
72)\end{array}$ & $\begin{array}{l}P i-b \\
(\mathrm{RM} \\
208)\end{array}$ & $\begin{array}{c}P i 27(t) \\
(\mathrm{RM} \\
259)\end{array}$ & $\begin{array}{l}P i k-h \\
(\mathrm{RM} \\
206)\end{array}$ & $\begin{array}{l}P i-t a \\
\text { (RM } \\
247)\end{array}$ & $\begin{array}{c}\text { Total } \\
\text { number } \\
\text { of genes }\end{array}$ \\
\hline 1 & Dular & IRRI, Philippines & 0 & 1 & 0 & 0 & 1 & 0 & 0 & 0 & 1 & 0 & 3 \\
\hline 2 & FR13A & IRRI, Philippines & 1 & 1 & 1 & 0 & 0 & 1 & 0 & 0 & 1 & 0 & 5 \\
\hline 3 & FR13B & IRRI, Philippines & 1 & 1 & 0 & 1 & 1 & 1 & 1 & 0 & 1 & 0 & 7 \\
\hline 4 & Karkati 87 & IRRI, Philippines & 0 & 0 & 1 & 1 & 1 & 0 & 1 & 0 & 0 & 0 & 4 \\
\hline 5 & Birpala & IRRI, Philippines & 1 & 0 & 1 & 1 & 1 & 0 & 0 & 0 & 1 & 0 & 5 \\
\hline 6 & Goda Heenati & IRRI, Philippines & 1 & 0 & 1 & 0 & 0 & 0 & 0 & 1 & 0 & 0 & 3 \\
\hline 7 & IR-64 Sub-1 & NRCPB, New Delhi, India & 1 & 0 & 0 & 0 & 0 & 1 & 1 & 0 & 0 & 0 & 3 \\
\hline 8 & Heensulai & IRRI, Philippines & 1 & 0 & 1 & 1 & 0 & 0 & 1 & 0 & 0 & 0 & 4 \\
\hline 9 & Madal & IRRI, Philippines & 1 & 0 & 1 & 1 & 0 & 1 & 1 & 0 & 0 & 0 & 5 \\
\hline 10 & Mahadikwee & IRRI, Philippines & 1 & 0 & 0 & 1 & 1 & 1 & 0 & 0 & 0 & 0 & 4 \\
\hline 11 & Ausboro & IRRI, Philippines & 1 & 0 & 0 & 0 & 0 & 1 & 1 & 1 & 1 & 0 & 5 \\
\hline 12 & Jaldungi & IRRI, Philippines & 1 & 0 & 0 & 0 & 1 & 0 & 1 & 1 & 1 & 0 & 5 \\
\hline 13 & Nirboi & IRRI, Philippines & 1 & 1 & 0 & 0 & 0 & 0 & 0 & 1 & 0 & 0 & 3 \\
\hline 14 & CR-1009 & IRRI, Philippines & 1 & 1 & 0 & 0 & 0 & 1 & 0 & 1 & 1 & 0 & 5 \\
\hline 15 & Hourakani & IRRI, Philippines & 1 & 0 & 0 & 1 & 1 & 1 & 1 & 1 & 1 & 0 & 7 \\
\hline 16 & Naldak & IRRI, Philippines & 1 & 1 & 0 & 0 & 1 & 0 & 1 & 1 & 0 & 0 & 5 \\
\hline 17 & Lunishree & CRRI, Cuttack, India & 1 & 1 & 0 & 1 & 0 & 0 & 1 & 1 & 0 & 1 & 6 \\
\hline 18 & Swarna Sub-1 & NRCPB, New Delhi, India & 1 & 1 & 0 & 0 & 0 & 1 & 1 & 1 & 1 & 0 & 6 \\
\hline 19 & Sambha Sub-1 & NRCPB, New Delhi, India & 1 & 0 & 1 & 1 & 0 & 1 & 1 & 1 & 0 & 0 & 6 \\
\hline 20 & Kariywa & NRCPB, New Delhi, India & 1 & 1 & 0 & 1 & 0 & 1 & 1 & 0 & 1 & 0 & 6 \\
\hline 21 & S-155 & CRRI, Cuttack, India & 0 & 1 & 0 & 0 & 0 & 1 & 0 & 1 & 0 & 0 & 3 \\
\hline 22 & Tsao Wanching & IRRI, Philippines & 1 & 1 & 1 & 1 & 0 & 1 & 0 & 1 & 0 & 0 & 6 \\
\hline 23 & JC-1 & IRRI, Philippines & 0 & 1 & 1 & 0 & 0 & 1 & 0 & 1 & 0 & 0 & 4 \\
\hline 24 & Lumbini & IRRI, Philippines & 0 & 0 & 0 & 0 & 1 & 0 & 1 & 1 & 1 & 1 & 5 \\
\hline 25 & Madhukar & IRRI, Philippines & 1 & 1 & 1 & 0 & 0 & 1 & 0 & 0 & 0 & 0 & 4 \\
\hline 26 & $\mathrm{~N}-22$ & IRRI, Philippines & 0 & 0 & 0 & 0 & 1 & 1 & 1 & 1 & 1 & 0 & 5 \\
\hline 27 & Binulawan & IRRI, Philippines & 0 & 1 & 0 & 1 & 0 & 0 & 1 & 0 & 0 & 0 & 3 \\
\hline 28 & Kala Rata 1-24 & IRRI, Philippines & 1 & 1 & 0 & 1 & 1 & 1 & 1 & 1 & 0 & 0 & 7 \\
\hline 29 & Tatan & IRRI, Philippines & 1 & 0 & 1 & 0 & 0 & 0 & 0 & 0 & 1 & 1 & 4 \\
\hline 30 & Bapakribuna & IRRI, Philippines & 1 & 0 & 1 & 0 & 0 & 1 & 0 & 0 & 0 & 0 & 3 \\
\hline 31 & Gota & IRRI, Philippines & 1 & 0 & 0 & 1 & 1 & 1 & 1 & 0 & 1 & 0 & 6 \\
\hline 32 & Khaiyen & IRRI, Philippines & 0 & 0 & 0 & 1 & 0 & 1 & 1 & 1 & 1 & 0 & 5 \\
\hline 33 & Kamnan & IRRI, Philippines & 1 & 1 & 1 & 0 & 0 & 0 & 0 & 0 & 0 & 0 & 3 \\
\hline 34 & Lemont & IRRI, Philippines & 1 & 1 & 1 & 1 & 1 & 1 & 0 & 0 & 1 & 0 & 7 \\
\hline 35 & Latsika & IRRI, Philippines & 0 & 0 & 1 & 0 & 1 & 1 & 0 & 1 & 0 & 0 & 4 \\
\hline 36 & Akita Komachi & IRRI, Philippines & 1 & 1 & 0 & 0 & 0 & 0 & 0 & 0 & 0 & 0 & 2 \\
\hline 37 & M-202 & IRRI, Philippines & 0 & 1 & 1 & 0 & 0 & 1 & 1 & 0 & 1 & 0 & 5 \\
\hline 38 & Amaroo & IRRI, Philippines & 0 & 1 & 1 & 0 & 1 & 0 & 1 & 0 & 0 & 0 & 4 \\
\hline 39 & Nipponbare & IRRI, Philippines & 0 & 1 & 1 & 0 & 1 & 0 & 1 & 0 & 0 & 0 & 4 \\
\hline 40 & Asami Dhan & IRRI, Philippines & 0 & 0 & 1 & 0 & 1 & 0 & 1 & 0 & 0 & 0 & 3 \\
\hline 41 & Chanyngat & IRRI, Philippines & 0 & 0 & 1 & 1 & 1 & 1 & 0 & 1 & 0 & 0 & 5 \\
\hline 42 & Budkodi & IRRI, Philippines & 1 & 0 & 1 & 1 & 1 & 1 & 0 & 1 & 0 & 0 & 6 \\
\hline 43 & Dub Gelong & IRRI, Philippines & 0 & 0 & 1 & 0 & 1 & 1 & 1 & 0 & 1 & 0 & 5 \\
\hline 44 & Sawitri & IRRI, Philippines & 0 & 0 & 0 & 0 & 0 & 1 & 1 & 1 & 0 & 0 & 3 \\
\hline
\end{tabular}


Table 2. Continued

\begin{tabular}{|c|c|c|c|c|c|c|c|c|c|c|c|c|c|}
\hline \multirow[b]{2}{*}{ S.No. } & \multirow[b]{2}{*}{ Accession Number } & \multirow[b]{2}{*}{ Source } & \multicolumn{11}{|c|}{ Blast resistance genes } \\
\hline & & & $\begin{array}{l}P i z-5 \\
(\mathrm{RM} \\
527)\end{array}$ & $\begin{array}{l}P i-9 \\
\text { (RM } \\
541)\end{array}$ & $\begin{array}{c}\text { Pitp(t) } \\
\text { (RM } \\
246)\end{array}$ & $\begin{array}{l}P i-1 \\
(\mathrm{RM} \\
224)\end{array}$ & $\begin{array}{c}P i-5(t) \\
(\mathrm{RM} \\
21)\end{array}$ & $\begin{array}{c}P i-33 \\
(\mathrm{RM} \\
72)\end{array}$ & $\begin{array}{l}P i-b \\
(\mathrm{RM} \\
208)\end{array}$ & $\begin{array}{c}P i 27(t) \\
(\mathrm{RM} \\
259)\end{array}$ & $\begin{array}{l}P i k-h \\
(\mathrm{RM} \\
206)\end{array}$ & $\begin{array}{l}P i-t a \\
\text { (RM } \\
247)\end{array}$ & $\begin{array}{c}\text { Total } \\
\text { number } \\
\text { of genes }\end{array}$ \\
\hline 45 & Asthu Bhejna & IRRI, Philippines & 0 & 0 & 0 & 0 & 0 & 0 & 1 & 0 & 0 & 0 & 1 \\
\hline 46 & Tundaniya & IRRI, Philippines & 1 & 0 & 1 & 0 & 0 & 0 & 1 & 0 & 1 & 0 & 4 \\
\hline 47 & MTU-7029 & BHU, Varanasi, India & 1 & 0 & 1 & 0 & 1 & 1 & 0 & 1 & 1 & 0 & 6 \\
\hline 48 & Sarjoo-52 & BHU, Varanasi, India & 1 & 0 & 0 & 1 & 0 & 1 & 0 & 0 & 1 & 0 & 4 \\
\hline 49 & HUR-105 & BHU, Varanasi, India & 1 & 0 & 1 & 0 & 0 & 1 & 1 & 0 & 0 & 0 & 4 \\
\hline 50 & HUR-3022 & BHU, Varanasi, India & 1 & 0 & 0 & 0 & 0 & 1 & 0 & 0 & 0 & 0 & 2 \\
\hline 51 & HUR-38B & BHU, Varanasi, India & 1 & 0 & 0 & 0 & 1 & 1 & 1 & 0 & 0 & 0 & 4 \\
\hline 52 & HUBR-40 & BHU, Varanasi, India & 1 & 1 & 0 & 0 & 0 & 1 & 1 & 0 & 0 & 1 & 5 \\
\hline 53 & HUBR 2-1 & BHU, Varanasi, India & 1 & 1 & 1 & 0 & 0 & 0 & 1 & 0 & 0 & 0 & 4 \\
\hline 54 & CB05-753-3 & BAU, Ranchi, India & 1 & 1 & 1 & 0 & 0 & 0 & 1 & 0 & 1 & 0 & 5 \\
\hline 55 & IR73000-98-1-2-1 & BAU, Ranchi, India & 1 & 1 & 0 & 0 & 0 & 1 & 0 & 1 & 1 & 0 & 5 \\
\hline 56 & Brown Gora & BAU, Ranchi, India & 0 & 1 & 1 & 1 & 1 & 1 & 1 & 1 & 0 & 0 & 7 \\
\hline 57 & IR82912-B-B-10 & BAU, Ranchi, India & 0 & 1 & 1 & 0 & 0 & 0 & 0 & 0 & 0 & 0 & 2 \\
\hline 58 & IR82910-B-B-67-2 & BAU, Ranchi, India & 1 & 0 & 1 & 1 & 0 & 0 & 0 & 0 & 0 & 0 & 3 \\
\hline 59 & UPRI2012-16 & BAU, Ranchi, India & 0 & 1 & 0 & 1 & 0 & 0 & 0 & 0 & 0 & 0 & 2 \\
\hline 60 & CR3488-1-2-1-2 & BAU, Ranchi, India & 1 & 1 & 1 & 0 & 1 & 0 & 0 & 0 & 0 & 0 & 4 \\
\hline 61 & IR82912-B-B-13 & BAU, Ranchi, India & 0 & 1 & 0 & 0 & 0 & 0 & 0 & 0 & 0 & 0 & 1 \\
\hline 62 & IR83926-B-B-71-4 & BAU, Ranchi, India & 1 & 1 & 1 & 0 & 0 & 0 & 1 & 0 & 0 & 0 & 4 \\
\hline 63 & CT15678-2-3-3-1 & BAU, Ranchi, India & 1 & 0 & 1 & 0 & 0 & 0 & 1 & 0 & 0 & 0 & 3 \\
\hline 64 & B10580E-KN-28 & BAU, Ranchi, India & 1 & 1 & 1 & 1 & 0 & 0 & 0 & 0 & 1 & 0 & 5 \\
\hline 65 & IR82635-B-B-93-2 & BAU, Ranchi, India & 1 & 1 & 1 & 0 & 0 & 0 & 0 & 0 & 0 & 0 & 3 \\
\hline 66 & BVD109 & BAU, Ranchi, India & 1 & 1 & 1 & 1 & 0 & 0 & 0 & 0 & 1 & 0 & 5 \\
\hline 67 & IR71146-97-1-2-1-3 & BAU, Ranchi, India & 1 & 1 & 1 & 0 & 0 & 0 & 0 & 0 & 0 & 0 & 3 \\
\hline 68 & IR82635-B-B-143-1 & BAU, Ranchi, India & 1 & 1 & 1 & 0 & 1 & 0 & 0 & 0 & 0 & 0 & 4 \\
\hline 69 & BAU408-05 & BAU, Ranchi, India & 0 & 1 & 0 & 0 & 0 & 0 & 0 & 0 & 0 & 0 & 1 \\
\hline 70 & IR82912-B-B-2 & BAU, Ranchi, India & 0 & 1 & 0 & 0 & 0 & 0 & 0 & 0 & 0 & 0 & 1 \\
\hline 71 & IR82912-B-B-7 & BAU, Ranchi, India & 1 & 1 & 1 & 0 & 0 & 0 & 0 & 0 & 0 & 0 & 3 \\
\hline 72 & IR83929-B-B-132-3 & BAU, Ranchi, India & 0 & 0 & 0 & 0 & 0 & 0 & 0 & 0 & 0 & 1 & 1 \\
\hline 73 & IRAT-112 & BAU, Ranchi, India & 1 & 1 & 0 & 0 & 0 & 0 & 0 & 1 & 1 & 0 & 4 \\
\hline 74 & IR87756-20-2-2-3 & BAU, Ranchi, India & 1 & 1 & 1 & 0 & 0 & 1 & 0 & 1 & 1 & 1 & 7 \\
\hline 75 & IR67017-124-2-4 & BAU, Ranchi, India & 0 & 0 & 0 & 1 & 0 & 0 & 0 & 1 & 1 & 0 & 3 \\
\hline 76 & B3688-TB-25-MR-2 & BAU, Ranchi, India & 1 & 0 & 0 & 0 & 1 & 0 & 0 & 1 & 1 & 0 & 4 \\
\hline 77 & BP19768-2-3-7-78-1-1 & I BAU, Ranchi, India & 1 & 0 & 0 & 1 & 1 & 0 & 0 & 1 & 1 & 0 & 5 \\
\hline 78 & IR78933-B-24-B-B-4 & BAU, Ranchi, India & 1 & 0 & 0 & 1 & 1 & 0 & 0 & 1 & 1 & 0 & 5 \\
\hline 79 & BP13510-1-2-PK-3-1 & BAU, Ranchi, India & 1 & 0 & 1 & 0 & 0 & 0 & 1 & 1 & 1 & 0 & 5 \\
\hline 80 & RR617-B-B-3 & BAU, Ranchi, India & 1 & 0 & 1 & 0 & 1 & 0 & 0 & 1 & 0 & 0 & 4 \\
\hline 81 & CR3423-1 & BAU, Ranchi, India & 0 & 0 & 1 & 0 & 0 & 0 & 0 & 1 & 0 & 0 & 2 \\
\hline 82 & CR1946-2-1 & BAU, Ranchi, India & 0 & 0 & 1 & 0 & 0 & 0 & 0 & 1 & 0 & 0 & 2 \\
\hline 83 & Kala Bunde & NRCPB, New Delhi, India & 0 & 0 & 0 & 0 & 0 & 0 & 1 & 0 & 1 & 0 & 2 \\
\hline 84 & IC260937 & DBT, New Delhi, India & 1 & 0 & 0 & 0 & 1 & 0 & 0 & 0 & 0 & 0 & 2 \\
\hline 85 & IC260961 & DBT, New Delhi, India & 1 & 0 & 0 & 0 & 1 & 0 & 0 & 0 & 0 & 0 & 2 \\
\hline 86 & IC260964 & DBT, New Delhi, India & 1 & 0 & 0 & 1 & 1 & 0 & 0 & 0 & 0 & 0 & 3 \\
\hline 87 & IC267416 & DBT, New Delhi, India & 0 & 0 & 0 & 0 & 1 & 0 & 1 & 0 & 0 & 0 & 2 \\
\hline 88 & IC278777 & DBT, New Delhi, India & 1 & 0 & 0 & 0 & 0 & 0 & 0 & 0 & 0 & 0 & 1 \\
\hline 89 & IC280466 & DBT, New Delhi, India & 1 & 0 & 1 & 0 & 0 & 0 & 0 & 0 & 0 & 0 & 2 \\
\hline
\end{tabular}


Table 2. Continued

\begin{tabular}{|c|c|c|c|c|c|c|c|c|c|c|c|c|c|}
\hline \multirow[b]{2}{*}{ S.No. } & \multirow[b]{2}{*}{ Accession Number } & \multirow[b]{2}{*}{ Source } & \multicolumn{11}{|c|}{ Blast resistance genes } \\
\hline & & & $\begin{array}{c}P i z-5 \\
(\mathrm{RM} \\
527)\end{array}$ & $\begin{array}{l}P i-9 \\
\text { (RM } \\
541)\end{array}$ & $\begin{array}{c}\text { Pitp(t) } \\
\text { (RM } \\
246)\end{array}$ & $\begin{array}{l}P i-1 \\
(\mathrm{RM} \\
224)\end{array}$ & $\begin{array}{c}P i-5(t) \\
(\mathrm{RM} \\
21)\end{array}$ & $\begin{array}{c}P i-33 \\
(\mathrm{RM} \\
72)\end{array}$ & $\begin{array}{l}P i-b \\
(\mathrm{RM} \\
208)\end{array}$ & $\begin{array}{c}P i 27(t) \\
(\mathrm{RM} \\
259)\end{array}$ & $\begin{array}{c}P i k-h \\
\text { (RM } \\
206)\end{array}$ & $\begin{array}{l}P i-t a \\
\text { (RM } \\
247)\end{array}$ & $\begin{array}{c}\text { Total } \\
\text { number } \\
\text { of genes }\end{array}$ \\
\hline 90 & IC281785 & DBT, New Delhi, India & 1 & 0 & 0 & 0 & 1 & 0 & 0 & 0 & 1 & 0 & 3 \\
\hline 91 & IC281786 & DBT, New Delhi, India & 0 & 1 & 1 & 1 & 0 & 1 & 0 & 1 & 0 & 1 & 6 \\
\hline 92 & IC282418 & DBT, New Delhi, India & 0 & 1 & 0 & 1 & 1 & 1 & 1 & 1 & 0 & 1 & 7 \\
\hline 93 & IC282443 & DBT, New Delhi, India & 0 & 1 & 0 & 1 & 1 & 0 & 0 & 0 & 0 & 1 & 4 \\
\hline 94 & IC282463 & DBT, New Delhi, India & 1 & 1 & 1 & 1 & 0 & 0 & 0 & 1 & 0 & 1 & 6 \\
\hline 95 & IC282471 & DBT, New Delhi, India & 1 & 1 & 1 & 1 & 0 & 0 & 0 & 1 & 0 & 1 & 6 \\
\hline 96 & IC282514 & DBT, New Delhi, India & 1 & 1 & 1 & 1 & 0 & 0 & 0 & 0 & 0 & 1 & 5 \\
\hline 97 & IC282808 & DBT, New Delhi, India & 1 & 1 & 0 & 1 & 0 & 0 & 0 & 0 & 0 & 1 & 4 \\
\hline 98 & IC282815 & DBT, New Delhi, India & 1 & 1 & 0 & 1 & 1 & 0 & 0 & 0 & 0 & 1 & 5 \\
\hline 99 & IC282816 & DBT, New Delhi, India & 1 & 1 & 0 & 1 & 1 & 0 & 0 & 0 & 0 & 0 & 4 \\
\hline 100 & IC282822 & DBT, New Delhi, India & 1 & 1 & 0 & 1 & 0 & 0 & 0 & 0 & 0 & 0 & 3 \\
\hline 101 & IC282824 & DBT, New Delhi, India & 1 & 1 & 0 & 1 & 0 & 0 & 0 & 0 & 0 & 0 & 3 \\
\hline 102 & IC331196 & DBT, New Delhi, India & 0 & 1 & 0 & 0 & 0 & 0 & 0 & 0 & 0 & 0 & 1 \\
\hline 103 & IC334180 & DBT, New Delhi, India & 0 & 1 & 1 & 1 & 1 & 0 & 0 & 0 & 0 & 1 & 5 \\
\hline 104 & IC337051 & DBT, New Delhi, India & 0 & 0 & 0 & 0 & 1 & 0 & 1 & 0 & 0 & 1 & 3 \\
\hline 105 & IC337367 & DBT, New Delhi, India & 0 & 0 & 0 & 0 & 0 & 1 & 0 & 0 & 0 & 1 & 2 \\
\hline 106 & IC337558 & DBT, New Delhi, India & 0 & 0 & 1 & 0 & 0 & 0 & 0 & 0 & 0 & 1 & 2 \\
\hline 107 & IC337578 & DBT, New Delhi, India & 0 & 0 & 0 & 1 & 1 & 1 & 1 & 0 & 0 & 0 & 4 \\
\hline 108 & IC337582 & DBT, New Delhi, India & 0 & 0 & 0 & 1 & 0 & 0 & 1 & 0 & 0 & 0 & 2 \\
\hline 109 & IC337588 & DBT, New Delhi, India & 1 & 1 & 1 & 0 & 0 & 1 & 1 & 0 & 0 & 1 & 6 \\
\hline 110 & IC337593 & DBT, New Delhi, India & 1 & 1 & 0 & 1 & 0 & 1 & 1 & 1 & 1 & 1 & 8 \\
\hline 111 & IC341351 & DBT, New Delhi, India & 1 & 1 & 1 & 0 & 0 & 1 & 0 & 1 & 0 & 1 & 6 \\
\hline 112 & IC346002 & DBT, New Delhi, India & 1 & 1 & 1 & 0 & 1 & 1 & 1 & 1 & 0 & 1 & 8 \\
\hline 113 & IC346004 & DBT, New Delhi, India & 1 & 1 & 1 & 1 & 0 & 1 & 1 & 1 & 0 & 1 & 8 \\
\hline 114 & IC346813 & DBT, New Delhi, India & 1 & 1 & 1 & 1 & 0 & 1 & 1 & 1 & 0 & 1 & 8 \\
\hline 115 & IC346880 & DBT, New Delhi, India & 1 & 1 & 0 & 0 & 0 & 1 & 0 & 1 & 0 & 1 & 5 \\
\hline 116 & IC356117 & DBT, New Delhi, India & 1 & 1 & 1 & 1 & 0 & 1 & 1 & 1 & 0 & 1 & 8 \\
\hline 117 & IC356419 & DBT, New Delhi, India & 1 & 1 & 0 & 1 & 0 & 1 & 0 & 1 & 1 & 1 & 7 \\
\hline 118 & IC356422 & DBT, New Delhi, India & 1 & 1 & 1 & 1 & 1 & 0 & 1 & 1 & 0 & 1 & 8 \\
\hline 119 & IC356429 & DBT, New Delhi, India & 1 & 1 & 0 & 1 & 0 & 0 & 0 & 1 & 0 & 1 & 5 \\
\hline 120 & IC356431 & DBT, New Delhi, India & 1 & 1 & 0 & 1 & 0 & 0 & 0 & 1 & 0 & 1 & 5 \\
\hline 121 & IC356432 & DBT, New Delhi, India & 1 & 1 & 0 & 1 & 0 & 0 & 0 & 1 & 0 & 1 & 5 \\
\hline 122 & IC356448 & DBT, New Delhi, India & 0 & 1 & 0 & 1 & 0 & 0 & 0 & 1 & 0 & 1 & 4 \\
\hline 123 & IC362206 & DBT, New Delhi, India & 0 & 1 & 0 & 0 & 1 & 0 & 0 & 1 & 0 & 1 & 4 \\
\hline 124 & IC382604 & DBT, New Delhi, India & 0 & 1 & 1 & 1 & 0 & 0 & 0 & 1 & 1 & 1 & 6 \\
\hline 125 & IC383396 & DBT, New Delhi, India & 0 & 1 & 0 & 0 & 1 & 0 & 0 & 1 & 0 & 1 & 4 \\
\hline 126 & IC383404 & DBT, New Delhi, India & 0 & 1 & 0 & 1 & 0 & 0 & 0 & 1 & 0 & 1 & 4 \\
\hline 127 & IC383441 & DBT, New Delhi, India & 1 & 1 & 1 & 1 & 1 & 1 & 0 & 1 & 0 & 1 & 8 \\
\hline 128 & IC383559 & DBT, New Delhi, India & 0 & 1 & 0 & 0 & 0 & 1 & 0 & 1 & 0 & 0 & 3 \\
\hline 129 & IC384176 & DBT, New Delhi, India & 0 & 0 & 1 & 0 & 0 & 1 & 0 & 1 & 0 & 0 & 3 \\
\hline 130 & IC384190 & DBT, New Delhi, India & 1 & 0 & 1 & 1 & 1 & 1 & 0 & 0 & 0 & 0 & 5 \\
\hline 131 & IC384260 & DBT, New Delhi, India & 1 & 1 & 0 & 0 & 0 & 1 & 0 & 0 & 0 & 0 & 3 \\
\hline 132 & IC391524 & DBT, New Delhi, India & 0 & 1 & 1 & 1 & 0 & 0 & 1 & 0 & 0 & 0 & 4 \\
\hline 133 & IC418382 & DBT, New Delhi, India & 0 & 0 & 0 & 0 & 0 & 0 & 1 & 0 & 1 & 0 & 2 \\
\hline 134 & IC426012 & DBT, New Delhi, India & 1 & 1 & 1 & 0 & 1 & 0 & 1 & 0 & 0 & 0 & 5 \\
\hline
\end{tabular}


Table 2. Continued

\begin{tabular}{|c|c|c|c|c|c|c|c|c|c|c|c|c|c|}
\hline \multirow[b]{2}{*}{ S.No. } & \multirow[b]{2}{*}{ Accession Number } & \multirow[b]{2}{*}{ Source } & \multicolumn{11}{|c|}{ Blast resistance genes } \\
\hline & & & $\begin{array}{l}P i z-5 \\
(\mathrm{RM} \\
527)\end{array}$ & $\begin{array}{l}P i-9 \\
(\mathrm{RM} \\
541)\end{array}$ & $\begin{array}{c}\operatorname{Pitp}(t) \\
(\mathrm{RM} \\
246)\end{array}$ & $\begin{array}{l}P i-1 \\
(\mathrm{RM} \\
224)\end{array}$ & $\begin{array}{c}P i-5(t) \\
(\mathrm{RM} \\
21)\end{array}$ & $\begin{array}{c}P i-33 \\
(\mathrm{RM} \\
72)\end{array}$ & $\begin{array}{l}P i-b \\
(\mathrm{RM} \\
208)\end{array}$ & $\begin{array}{c}P i 27(t) \\
(\mathrm{RM} \\
259)\end{array}$ & $\begin{array}{c}P i k-h \\
(\mathrm{RM} \\
206)\end{array}$ & $\begin{array}{l}P i-t a \\
(\mathrm{RM} \\
247)\end{array}$ & $\begin{array}{c}\text { Total } \\
\text { number } \\
\text { of genes }\end{array}$ \\
\hline 135 & IC426013 & DBT, New Delhi, India & 1 & 1 & 1 & 0 & 1 & 0 & 1 & 0 & 0 & 0 & 5 \\
\hline 136 & IC426017 & DBT, New Delhi, India & 1 & 1 & 1 & 0 & 1 & 1 & 1 & 0 & 0 & 0 & 6 \\
\hline 137 & IC426058 & DBT, New Delhi, India & 1 & 1 & 1 & 0 & 1 & 0 & 1 & 0 & 0 & 0 & 5 \\
\hline 138 & IC426060 & DBT, New Delhi, India & 0 & 1 & 0 & 1 & 0 & 0 & 1 & 0 & 0 & 0 & 3 \\
\hline 139 & IC426061 & DBT, New Delhi, India & 0 & 0 & 1 & 0 & 0 & 0 & 1 & 0 & 1 & 0 & 3 \\
\hline 140 & IC426137 & DBT, New Delhi, India & 0 & 0 & 1 & 0 & 0 & 0 & 0 & 0 & 0 & 0 & 1 \\
\hline 141 & IC438644 & DBT, New Delhi, India & 0 & 0 & 0 & 0 & 0 & 0 & 0 & 0 & 0 & 0 & 0 \\
\hline 142 & IC446975 & DBT, New Delhi, India & 0 & 0 & 1 & 0 & 0 & 0 & 1 & 0 & 0 & 0 & 2 \\
\hline 143 & EC545051 & DBT, New Delhi, India & 0 & 0 & 1 & 1 & 0 & 0 & 1 & 0 & 0 & 0 & 3 \\
\hline 144 & EC545061 & DBT, New Delhi, India & 0 & 0 & 1 & 0 & 0 & 1 & 1 & 0 & 0 & 0 & 3 \\
\hline 145 & PKSLGR-1 & BHU, Varanasi, India & 1 & 1 & 1 & 1 & 1 & 1 & 1 & 0 & 0 & 0 & 7 \\
\hline 146 & PKSLGR-2 & BHU, Varanasi, India & 1 & 1 & 1 & 0 & 1 & 0 & 0 & 0 & 0 & 0 & 4 \\
\hline 147 & PKSLGR-3 & BHU, Varanasi, India & 1 & 1 & 1 & 0 & 0 & 1 & 1 & 0 & 0 & 0 & 5 \\
\hline 148 & PKSLGR-4 & BHU, Varanasi, India & 0 & 1 & 0 & 1 & 1 & 0 & 0 & 0 & 0 & 0 & 3 \\
\hline 149 & PKSLGR-5 & BHU, Varanasi, India & 0 & 1 & 1 & 0 & 0 & 1 & 1 & 0 & 0 & 0 & 4 \\
\hline 150 & PKSLGR-6 & BHU, Varanasi, India & 0 & 1 & 0 & 1 & 1 & 0 & 0 & 0 & 0 & 0 & 3 \\
\hline 151 & PKSLGR-7 & BHU, Varanasi, India & 1 & 0 & 1 & 0 & 0 & 1 & 1 & 1 & 0 & 0 & 5 \\
\hline 152 & PKSLGR-8 & BHU, Varanasi, India & 1 & 0 & 1 & 0 & 1 & 1 & 1 & 1 & 0 & 0 & 6 \\
\hline 153 & PKSLGR-9 & BHU, Varanasi, India & 0 & 0 & 0 & 1 & 1 & 0 & 0 & 0 & 0 & 0 & 2 \\
\hline 154 & PKSLGR-10 & BHU, Varanasi, India & 0 & 0 & 0 & 1 & 1 & 0 & 0 & 0 & 0 & 0 & 2 \\
\hline 155 & PKSLGR-11 & BHU, Varanasi, India & 0 & 0 & 0 & 1 & 1 & 0 & 0 & 0 & 0 & 0 & 2 \\
\hline 156 & PKSLGR-12 & BHU, Varanasi, India & 0 & 0 & 0 & 1 & 1 & 1 & 0 & 0 & 0 & 0 & 3 \\
\hline 157 & PKSLGR-13 & BHU, Varanasi, India & 0 & 0 & 0 & 1 & 0 & 0 & 0 & 0 & 0 & 0 & 1 \\
\hline 158 & PKSLGR-14 & BHU, Varanasi, India & 0 & 0 & 0 & 1 & 0 & 0 & 0 & 0 & 0 & 0 & 1 \\
\hline 159 & PKSLGR-15 & BHU, Varanasi, India & 0 & 0 & 0 & 0 & 1 & 0 & 1 & 0 & 0 & 0 & 2 \\
\hline 160 & PKSLGR-16 & BHU, Varanasi, India & 0 & 0 & 0 & 1 & 1 & 0 & 0 & 0 & 0 & 0 & 2 \\
\hline 161 & PKSLGR-17 & BHU, Varanasi, India & 0 & 0 & 1 & 0 & 1 & 1 & 0 & 0 & 0 & 0 & 3 \\
\hline 162 & PKSLGR-18 & BHU, Varanasi, India & 0 & 0 & 1 & 0 & 1 & 0 & 0 & 0 & 0 & 0 & 2 \\
\hline 163 & PKSLGR-19 & BHU, Varanasi, India & 0 & 1 & 0 & 1 & 0 & 0 & 0 & 0 & 0 & 0 & 2 \\
\hline 164 & PKSLGR-20 & BHU, Varanasi, India & 1 & 1 & 0 & 0 & 0 & 1 & 0 & 0 & 1 & 0 & 4 \\
\hline 165 & PKSLGR-21 & BHU, Varanasi, India & 0 & 1 & 1 & 0 & 1 & 0 & 1 & 0 & 0 & 0 & 4 \\
\hline 166 & PKSLGR-22 & BHU, Varanasi, India & 0 & 1 & 0 & 1 & 0 & 0 & 0 & 0 & 0 & 0 & 2 \\
\hline 167 & PKSLGR-23 & BHU, Varanasi, India & 0 & 1 & 0 & 1 & 0 & 0 & 0 & 0 & 0 & 0 & 2 \\
\hline 168 & PKSLGR-24 & BHU, Varanasi, India & 0 & 1 & 1 & 1 & 0 & 0 & 1 & 0 & 0 & 0 & 4 \\
\hline 169 & PKSLGR-25 & BHU, Varanasi, India & 1 & 1 & 0 & 1 & 1 & 1 & 1 & 0 & 0 & 0 & 6 \\
\hline 170 & PKSLGR-26 & BHU, Varanasi, India & 0 & 0 & 1 & 0 & 1 & 0 & 1 & 0 & 1 & 0 & 4 \\
\hline 171 & PKSLGR-27 & BHU, Varanasi, India & 0 & 0 & 1 & 1 & 1 & 0 & 1 & 0 & 1 & 0 & 5 \\
\hline 172 & PKSLGR-28 & BHU, Varanasi, India & 0 & 1 & 1 & 0 & 1 & 0 & 1 & 0 & 0 & 0 & 4 \\
\hline 173 & PKSLGR-29 & BHU, Varanasi, India & 1 & 0 & 0 & 0 & 0 & 0 & 0 & 1 & 1 & 0 & 3 \\
\hline 174 & PKSLGR-30 & BHU, Varanasi, India & 1 & 1 & 1 & 1 & 1 & 0 & 1 & 0 & 0 & 0 & 6 \\
\hline 175 & PKSLGR-31 & BHU, Varanasi, India & 0 & 0 & 0 & 1 & 0 & 0 & 0 & 0 & 0 & 0 & 1 \\
\hline 176 & PKSLGR-32 & BHU, Varanasi, India & 0 & 0 & 0 & 0 & 0 & 0 & 0 & 0 & 1 & 0 & 1 \\
\hline 177 & PKSLGR-33 & BHU, Varanasi, India & 1 & 0 & 0 & 1 & 1 & 0 & 0 & 0 & 0 & 0 & 3 \\
\hline 178 & PKSLGR-34 & BHU, Varanasi, India & 1 & 0 & 0 & 0 & 1 & 0 & 0 & 1 & 0 & 0 & 3 \\
\hline 179 & PKSLGR-35 & BHU, Varanasi, India & 0 & 0 & 0 & 1 & 1 & 1 & 1 & 0 & 1 & 0 & 5 \\
\hline
\end{tabular}


Table 2. Continued

\begin{tabular}{|c|c|c|c|c|c|c|c|c|c|c|c|c|c|}
\hline \multirow[b]{2}{*}{ S.No. } & \multirow[b]{2}{*}{ Accession Number } & \multirow[b]{2}{*}{ Source } & \multicolumn{11}{|c|}{ Blast resistance genes } \\
\hline & & & $\begin{array}{l}\text { Piz-5 } \\
(\mathrm{RM} \\
527)\end{array}$ & $\begin{array}{l}P i-9 \\
\text { (RM } \\
541)\end{array}$ & $\begin{array}{c}\text { Pitp }(t) \\
(\mathrm{RM} \\
246)\end{array}$ & $\begin{array}{l}P i-1 \\
\text { (RM } \\
224)\end{array}$ & $\begin{array}{c}P i-5(t) \\
(\mathrm{RM} \\
21)\end{array}$ & $\begin{array}{c}P i-33 \\
(\mathrm{RM} \\
72)\end{array}$ & $\begin{array}{l}P i-b \\
\text { (RM } \\
208)\end{array}$ & $\begin{array}{c}P i 27(t) \\
(\mathrm{RM} \\
259)\end{array}$ & $\begin{array}{l}P i k-h \\
(\mathrm{RM} \\
206)\end{array}$ & $\begin{array}{l}P i-t a \\
(\mathrm{RM} \\
247)\end{array}$ & $\begin{array}{c}\text { Total } \\
\text { number } \\
\text { of genes }\end{array}$ \\
\hline 180 & PKSLGR-36 & BHU, Varanasi, India & 0 & 0 & 0 & 0 & 1 & 1 & 1 & 0 & 1 & 0 & 4 \\
\hline 181 & PKSLGR-37 & BHU, Varanasi, India & 1 & 0 & 1 & 1 & 0 & 1 & 0 & 0 & 0 & 0 & 4 \\
\hline 182 & PKSLGR-38 & BHU, Varanasi, India & 1 & 1 & 0 & 1 & 0 & 1 & 0 & 1 & 1 & 0 & 6 \\
\hline 183 & PKSLGR-39 & BHU, Varanasi, India & 1 & 1 & 0 & 1 & 1 & 1 & 0 & 1 & 0 & 1 & 7 \\
\hline 184 & PKSLGR-40 & BHU, Varanasi, India & 1 & 1 & 0 & 1 & 0 & 1 & 0 & 1 & 1 & 0 & 6 \\
\hline 185 & PKSLGR-41 & BHU, Varanasi, India & 1 & 0 & 1 & 0 & 0 & 1 & 0 & 0 & 1 & 0 & 4 \\
\hline 186 & PKSLGR-42 & BHU, Varanasi, India & 0 & 1 & 1 & 0 & 0 & 1 & 0 & 0 & 1 & 0 & 4 \\
\hline 187 & PKSLGR-43 & BHU, Varanasi, India & 0 & 1 & 0 & 1 & 0 & 0 & 0 & 0 & 1 & 0 & 3 \\
\hline 188 & PKSLGR-44 & BHU, Varanasi, India & 0 & 0 & 0 & 0 & 1 & 0 & 0 & 0 & 0 & 0 & 1 \\
\hline 189 & PKSLGR-45 & BHU, Varanasi, India & 0 & 0 & 1 & 0 & 1 & 1 & 0 & 0 & 0 & 0 & 3 \\
\hline 190 & PKSLGR-46 & BHU, Varanasi, India & 0 & 0 & 1 & 0 & 0 & 1 & 0 & 0 & 0 & 0 & 2 \\
\hline 191 & PKSLGR-47 & BHU, Varanasi, India & 0 & 0 & 1 & 0 & 0 & 1 & 0 & 0 & 0 & 0 & 2 \\
\hline 192 & PKSLGR-48 & BHU, Varanasi, India & 0 & 0 & 0 & 1 & 1 & 1 & 0 & 0 & 1 & 0 & 4 \\
\hline \multicolumn{3}{|c|}{ Frequency (\%) } & 54.69 & 52.60 & 47.92 & 44.27 & 40.63 & 40.10 & 39.06 & 33.85 & 27.08 & 19.79 & \\
\hline \multicolumn{3}{|c|}{ Approx. size (bp) } & 216 & 170 & 120 & 140 & 147 & 160 & 170 & 150 & 130 & 126 & \\
\hline
\end{tabular}

The rice blast resistance gene scored as the presence (1) and absence (0) of amplicon linked to ten of allele specific SSR markers.

mixture containing $30 \mathrm{ng}$ genomic DNA, $1.5 \mathrm{mM}$ PCR buffer (MBI Fermentas, USA), $400 \mu \mathrm{M}$ dNTPs (MBI Fermentas), 1 U Taq DNA polymerase (MBI Fermentas) and $0.4 \mu \mathrm{M}$ primer using a thermal cycler (Mastercycler gradient, Eppendorf). Thermal cycling program involved an initial denaturation at $94^{\circ} \mathrm{C}$ for $4 \mathrm{~min}$, followed by 34 cycles of denaturation at $94^{\circ} \mathrm{C}$ for $45 \mathrm{sec}$, annealing at $2^{\circ} \mathrm{C}$ below $\mathrm{Tm}$ of respective primers for $30 \mathrm{sec}$, primer extension at $72^{\circ} \mathrm{C}$ for $30 \mathrm{sec}$, followed by a final extension at $72^{\circ} \mathrm{C}$ for 8 min. SSR markers (Co-dominant) show specific site banding pattern on chromosome for specific traits. The $2.5 \%$ agarose gel was used for visualising banding pattern $>20$ bp product size between the alleles. The amplified PCR products with a 50 bp DNA marker ladder (MBI Fermentas) were size fractioned by electrophoresis in $2.5 \%$ agarose gel prepared in TAE buffer and visualized by staining with ethidium bromide $(0.5 \mu \mathrm{g} / \mathrm{ml})$ in a gel documentation system (BIO-RAD, USA).

\section{Results}

Allelic diversity of rice blast resistance genes. The results of genotypic screening of 192 accessions for the presence or absence of 10 major rice blast resistance genes using SSR markers are presented in Table 2 and electrophoresis pattern of each SSR marker linked to blast resistant gene with few accessions are shown in Fig. 1A\&B. The germ- plasms PB-1460 for Pi-9, Pi-1, Pi-5(t), Piz-5, Pi-b, Pi-ta; IR-64 for $P i-33, P i 27(t)$ and Tetep for Pitp $(t), P i-k^{h}$ were used as gene differential lines. Estimation of PCR results for 10 blast resistance genes viz. Piz-5, Pi-9, Pitp(t), Pi-1, $P i-5(t), P i-33, P i-b, P i 27(t), P i-k^{h}$ and $P i-t a$ were determined by visualization of amplicons on near $216 \mathrm{bp}, 170$ bp, 120 bp, 140 bp, 147 bp, 160 bp, 170 bp, 150 bp, 130 $\mathrm{bp}$ and $126 \mathrm{bp}$ of positive fragments, respectively. The genetic frequencies of the 10 major rice blast resistance genes were ranged from $19.79 \%$ to $54.69 \%$. Seventy three accessions containing at least five positive bands of the 10 rice blast resistance markers. The blast resistance gene Piz5 was widely distributed in $54.69 \%$ accessions followed by $P i-9$ in $52.60 \%$, Pitp(t) in $47.92 \%, P i-1$ in $44.27 \%, P i$ $5(t)$ in $40.63 \%, P i-33$ in $40.10 \%, P i b$ in $39.06 \%, P i-27(t)$ in $33.85 \%$, Pik- $h$ in $27.08 \%$ and Pi-ta in only $19.79 \%$ accessions. Seven accessions IC337593, IC346002, IC346004, IC346813, IC356117, IC356422 and IC383441 had maximum eight blast resistance gene, while FR13B, Hourakani, Kala Rata 1-24, Lemont, Brown Gora, IR87756-20-2-2-3, IC282418, IC356419, PKSLGR-1 and PKSLGR-39 possessed seven blast resistance genes, and 20 accessions had six genes, 36 accessions had five genes, 41 accessions had four genes, 38 accessions had three genes, 26 accessions had two genes, 13 accessions had single $R$ gene and only one accession IC438644 does not possess any one blast resistant gene. 

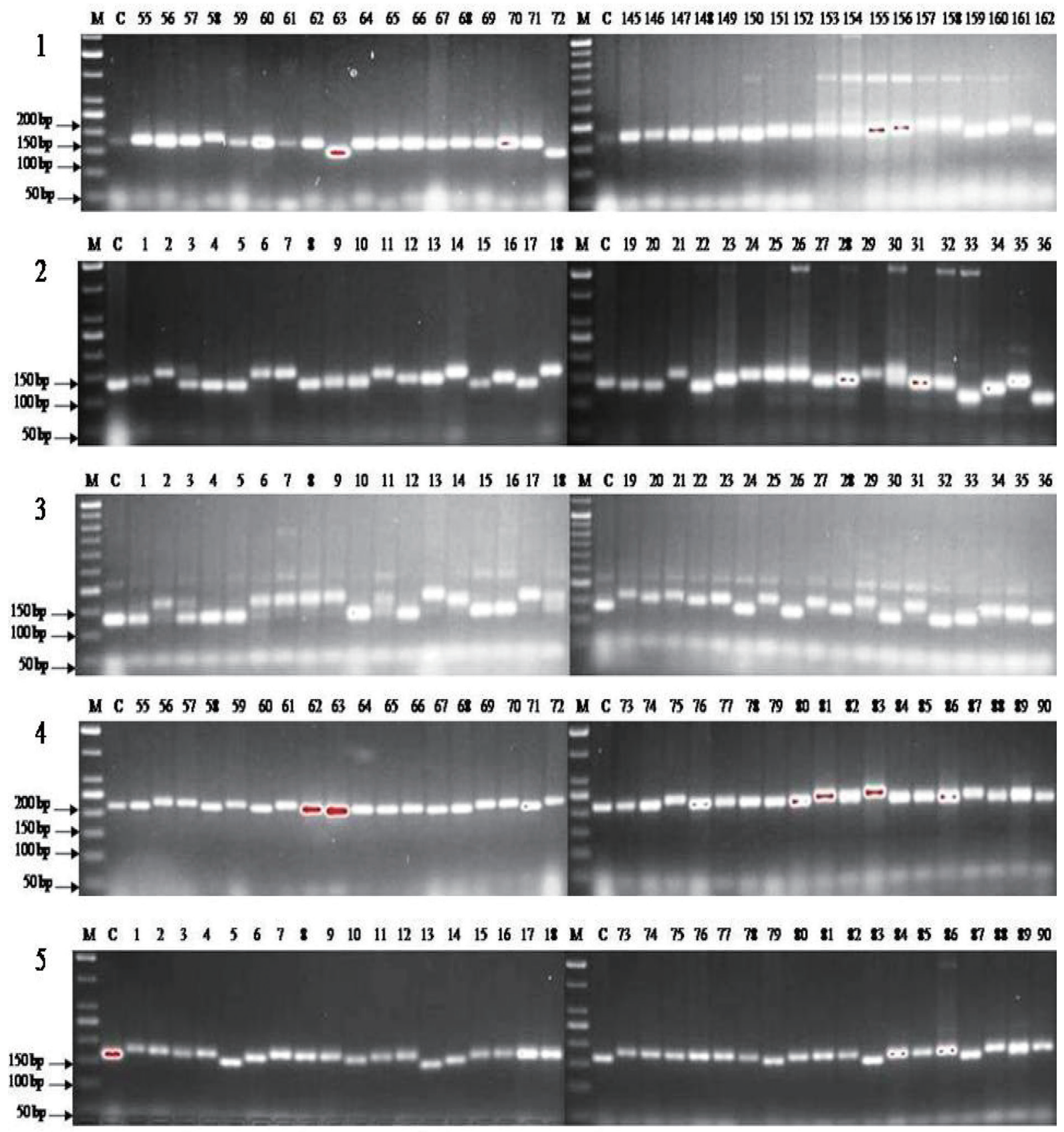

Fig. 1. (A) Agarose gel electrophoretic pattern of some selected rice germplasm accessions generated by using SSR markers (1) RM 541, (2) RM 224, (3) RM 21, (4) RM 527, (5) RM 208, where M is 50 bp DNA size marker, C is check variety and numbers 1-192 represent rice germplasm accessions as described in Table 2.

Genetic diversity of $P \boldsymbol{P}-1$ and $P \boldsymbol{P}-9$ gene. Estimation of PCR results for the $P i-1$ and $P i-9$ rice blast resistance genes were determined by visualization of amplicons on $140 \mathrm{bp}$ and $170 \mathrm{bp}$ of positive fragments using SSR primer RM 224 and RM 541 on the chromosome number 11 and 6, respectively. $P i-1$ gene was scored on 85 accessions and
$P i-9$ gene in 101 accessions. $P i-9$ gene fragment was the second most prevalent among the germplasm accessions studied. Fifty one accessions amplify both SSR markers corresponding to the resistance check (PB 1460) while 57 accessions did not amplify either of the two markers and hence negative for these two genes. 

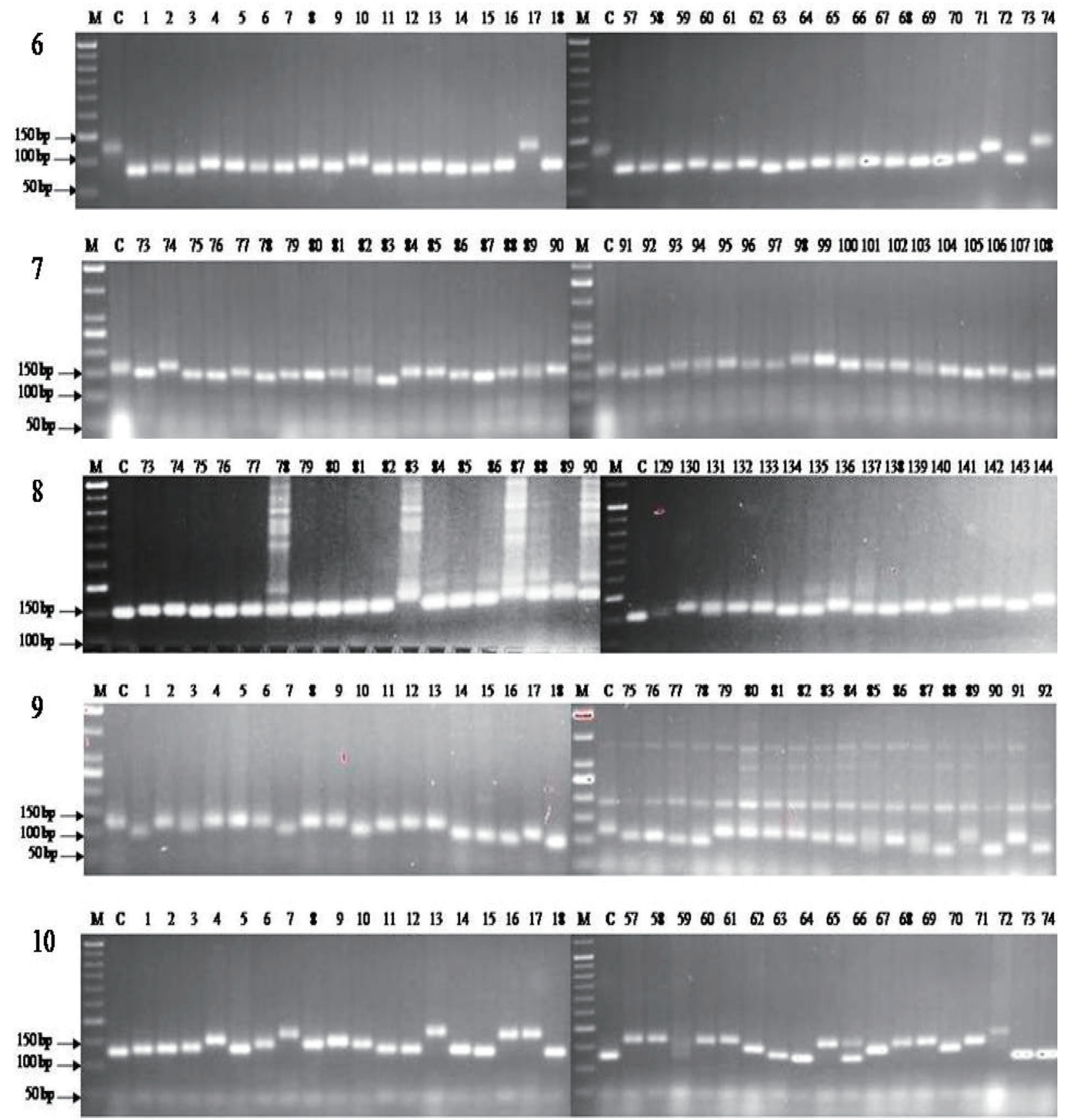

Fig. 1. (B) Agarose gel electrophoretic pattern of some selected rice germplasm accessions generated by using SSR markers (6) RM 247, (7) RM 72, (8) RM 259, (9) RM 246, (10) RM 206, where M is 50 bp DNA size marker, C is check variety and numbers 1-192 represent rice germplasm accessions as described in Table 2.

Genetic diversity of $P i-5(t)$ and $P i z-5$ gene. The SSR marker RM 21 is linked to blast resistance gene Pi5-(t) on chromosome no. 11, revealed the presence of a $147 \mathrm{bp}$ fragment specific for Pi5-( $t$ ) mediated blast resistance in the differential line PB 1460. Presence of rice blast resistance gene Piz-5 on chromosome 6 was determined by visualization of positive fragments using SSR primer RM
527 on $216 \mathrm{bp}$ of positive fragment corresponding to the resistance differential line PB 1460. Piz-5 gene fragment was the most prevalent among the accessions studied. Forty accessions possessing both genes corresponding to the resistance check (PB 1460) while 51 accessions did not amplify either of the two markers and hence negative for the two genes. 
Genetic diversity of $\boldsymbol{P} \boldsymbol{i}$-t $\boldsymbol{a}$ and $\boldsymbol{P} \boldsymbol{i}-\boldsymbol{b}$ gene: PCR based screening of $P i-t a$ and $P i-b$ genes on chromosome 12 and 2 showed that only 38 and 75 accessions under study produced positive bands on $126 \mathrm{bp}$ and $170 \mathrm{bp}$ with SSR marker RM 247 and RM 208, respectively. Eighty nine accessions possessed at least one of $\mathrm{Pi}$-ta/Pi-b genes. Twelve accessions amplify both SSR markers corresponding the resistance check (PB 1460) while 91 accessions did not amplify either of the two markers and hence negative for the two genes.

Genetic diversity of $P \boldsymbol{i}-27(t)$ and $P \boldsymbol{i}-33$ gene. The $P i$ 27(t) and $P i-33$ specific PCR primer RM 259 and RM 72 were produced $150 \mathrm{bp}$ and $160 \mathrm{bp}$ amplicon based on its sequence on chromosome 6 and 8, respectively. Screening of $\mathrm{Pi}-27(\mathrm{t})$ and $\mathrm{Pi}-33$ blast resistance gene were determined by visualization of positive fragments from 65 and 77 accessions with SSR marker RM 259 and RM 72, respectively. The 37 accessions amplify both SSR markers corresponding to the resistance check (IR 64) while 87 accessions did not amplify either of the two SSR markers which showed negative for the two genes.

Genetic diversity of $P i-k^{h}$ and $P i t p(t)$ gene. Fifty two accessions show the positive fragment of $P i-k^{h}$ gene located on chromosome 11 with tightly linked SSR markers RM 206, while 92 accessions show the positive gragment of Pitp $(t)$ located on chromosome 11 with tightly linked SSR markers RM 246. Result indicates the presence of an approx $130 \mathrm{bp}$ and $120 \mathrm{bp}$ fragment specific for blast resistance genes $P i-k^{h}$ and Pitp $(t)$ in the differential Tetep, respectively. Eighteen accessions showed positive bands for both genes while 68 accessions did not amplify any of the two genes.

\section{Discussion}

The marker-assisted selection of rice blast resistance genes will help in the breeding program in multi-diseases resistant rice varieties in genetic resources of rice. Some of these germplasm accessions may have special properties that are important to breeding program. In the present study, the genetic frequencies of the 10 major rice blast resistance genes Piz-5, Pi-9, Pitp(t), Pi-1, Pi-5(t), Pi-33, $P i-b, P i 27(t), P i-k^{h}$ and $P i$-ta were ranged from $19.79 \%$ to $54.69 \%$. Similar results were reported by Kim et al. (2010) in 84 accessions of rice germplasms possessed more than three positive bands of the eight rice blast resistance genes, and Imam et al. (2014) reported the genetic frequency of the nine major rice blast resistance genes Piz, Piz-t, Pik,
Pik-p, Pik-h, Pita/Pita-2, pita, Pi9 and Pib, ranged from 6 to $97 \%$ in the select set of rice germplasms. Our result also showed that the analysis of the distribution of resistance genes in ancient populations of landraces can direct the rice blast resistance breeding program and rice blast control by genetic diversity. Many rice varieties have been developed as completely resistant to $M$. oryzae strains, but soon breakdown of rice blast resistant genes occurred because of the emergence of stronger virulent isolates of rice blast fungus (Mackill and Bonman, 1992). Genotyping of the accessions with allele specific markers helped to identify 10 major blast resistance genes in 192 rice germplasm accessions from different ecological regions.

The $54.69 \%$ accessions possessing resistance gene Piz5 on chromosome 6 . These accessions were distributed in different ecosystem across the globe. Similarly, Yan et al. (2007) evaluated a core subset of the USDA 1790 rice germplasms and they found some accessions contained $P i z-5$ gene with additional $\mathrm{R}$ genes. In addition we verified accuracy of our results, 105 accessions possessed identical alleles for Piz-5 gene at approximate 216 bp fragments corresponding to the check (PB 1460). The presence of the same marker alleles in these accessions suggests that they contain a Piz-5 gene. This finding is important because these 105 accessions were collected from different geographic regions. The most likely reason for this similarity is that the original donor parent for the Piz-5 gene may contain the same genomic fragment for all these cultivars. In contrast, 87 accessions do not showed similar marker allele suggesting that these accessions presumably either inherited from different donors or the result of recombination during the breeding process. In conclusion, we not only verified the Piz-5 gene in 105 accessions using previously identified DNA markers but also demonstrated the usefulness of DNA markers with differential blast resistance gene for germplasm characterization. Similar report also made earlier by Roy-Chowdhury et al. (2012b).

The resistance pattern of the accessions is examined for the presence of amplicon products of the major genes. It was noted that though resistance is generally proportional to the frequency of the resistant gene(s). The present study was taken up with a selected set of rice accessions covering a wider geographical region where certain genes (Piz5, Pi9, Pitp ( $t$ ) and $P i-1)$ were more diverse than others and these were identified in 105, 101, 92 and 85 accessions on chromosome 6, 6, 1 and 11, respectively. Similarly, Imam et al. (2014) reported in his study that the genes (Pi9, Pita2, Piz- $t$ ) were more effective than others in thwarting infection. Thirty eight accessions produced positive bands near $126 \mathrm{bp}$ fragments corresponding to the check (PB 1460) for 
blast resistance gene $\mathrm{Pi}$-ta, which has been located near the centromere of chromosome 12 (Wang et al., 2002). Identification and validation of $\mathrm{Pi}$-ta genes reveals that the Indian rice germplasm are diverse and potential source of blast resistant lines which can be exploited in rice blast breeding programs (Shikari et al., 2013). The Pi-ta genes commonly used in rice breeding programs worldwide have originated from several traditional indica cultivars, including Tetep from Veitnam and Tadukan from the Philippines (Cho et al., 2008). Transferring blast resistance genes to different genetic backgrounds is very cumbersome and tedious. Since, it would be difficult to identify under field conditions using conventional approaches in order for markerassisted selection to facilitate at early selection phase with greater accuracy (Gu et al., 2005).

Molecular screening of $P i k-h$ and $P i-b$ blast resistance gene were determined by visualization of positive fragments from 52 and 75 accessions, respectively. Members of the $P i k$ - $h$ multi-gene family and $P i-b$ were moderately distributed genes in the present study but neither the germplasm possessing them nor the isogenic lines in the previous evaluations had exhibited resistance (Variar et al., 2009). Presence of major rice blast resistance gene Pitp $(t)$ and $P i-27(t)$ on chromosome 1 and $P i-33$ on chromosome 8 was determined by visualization of $120 \mathrm{bp}, 150 \mathrm{bp}$ and $160 \mathrm{bp}$ positive fragments, respectively. The gene-specific marker RM 246 for resistance gene Pitp $(t)$ amplified positive bands in 85 accessions, while $P i-27(t)$ and $P i-33$ genes were identified in 65 and 77 accessions, respectively. This study illustrated the utility of SSR markers to identify rice varieties likely carried the same $R$ genes with potentially novel resistance. Rice varieties with a number of alleles in common with any specific resistance might have a similar blast $R$ gene, and understanding the natural diversity at the specific gene is important for incorporation of specific $R$ gene using DNA marker into rice breeding program (Jia et al., 2003).

Genetic diversity among the rice accessions and within the pathogen often leads to inconsistent marker and phenotype analysis. MAS have the advantage in identifying $\mathrm{R}$ genes, but its power lies in the robustness of the markers used. The identification and analysis of rice blast resistance genes suggests that DNA primers derived from the gene is a valuable tool for blast gene identification and screening among the rice germplasm (Roy-Chowdhury et al., 2012a, b). In this study, the PCR based markers employed for screening of different blast resistance genes are well established and effective. The consistent results showed with the selected SSR markers for respective genes was highly reliable and make them the marker of choice for molecu- lar screening of rice blast resistance genes among the rice accessions. Plant breeders often use cultivars developed in other countries to broaden the genetic background of the improved cultivars being developed such as the major fungal diseases of blast, but most breeding programs of rice have a narrow genetic diversity of breeding resources. Our results showed that 17 accessions harboured 7 to 8 blast resistance genes, which can be suggested that these accessions could be used as sources of resistance genes in designing future breeding programmes, and there is good possibility of obtaining enhanced resistance through gene pyramiding.

\section{Acknowledgement}

Authors are thankful to Department of Biotechnology, New Delhi, Ministry of Agriculture, Government of India for their financial support through Grant No. 07/473, BHU Varanasi India.

\section{References}

Ashikawa, I., Hayashi, N., Yamane, H., Kanamori, H., Wu, J., Matsumoto, T., Ono, K. and Yano, M. 2008. Two adjacent nucleotide- binding site-leucine-rich repeat class genes are required to confer Pikm-specific rice blast resistance. Genetics 180:2267-2276.

Ballini, E., Morel, J. B., Droc, G., Price, A., Courtois, B., Notteghem, J. L. and Tharreau, D. 2008. A genome-wide metaanalysis of rice blast resistance genes and quantitative trait loci provides new insights into partial and complete resistance. Mol. Plant-Microbe Interact. 21:859-868.

Barman, S. R., Gowda, M., Venu, R. C. and Chattoo, B. B. 2004. Identification of a major blast resistance gene in the rice cultivar Tetep. Plant Bleed. 123:300-302.

Berruyer, R., Adreit, H., Milazzo, J., Gaillard, S., Berger, A., Dioh, W., Lebrun, M. H. and Tharreau, D. 2003. Identification and fine mapping of Pi33, the rice resistance gene corresponding to the Magnaporthe grisea avirulence gene ACE1. Theor. Appl. Genet. 107:1139-1147.

Bryan, G. T., Wu, K. S., Farrall, L., Jia, Y. L., Hershey, H. P., McAdams, S. A., Faulk, K. N., Donaldson, G. K., Tarchini, R. and Valent, B. 2000. A single amino acid difference distinguishes resistant and susceptible alleles of the rice blast resistance gene Pi-ta. Plant Cell 12:2033-2045.

Chauhan, S., Farman, M. L., Zhang H. B. and Leong, N. 2002. Genetic and physical mapping of a rice blast resistance locus, $\operatorname{PiCO39}(t)$, that corresponds to the avirulence gene AVR1- CO39 of Magnaporthe grisea. Mol. Genet. Genomics 267:603-612.

Chen, J., Shi, Y., Liu, W., Chai, R., Fu, Y., Zhuang, J. and Wu, J. 2011. A Pid3 allele from rice cultivar Gumei-2 confers resistance to Magnaporthe oryzae. J. Genet. Genomics 38:209- 
216.

Chen, M., Presting, G. and Barbazuk, W. B. 2002. An integrated physical and genetic map of the rice genome. Plant Cell 14:537-545.

Chen, X., Shang, J., Chen, D., Lei, C., Zou, Y., Zhai, W., Liu, G., Xu, J., Ling, Z., Cao, G., Ma, B., Wang, Y., Zhao, X., Li, S. and Zhu, L. 2006. A B-lectin receptor kinase gene conferring rice blast resistance. Plant J. 46:794-804.

Cho, Y. C., Jeung, J. U., Park, H. J., Yang, C. I., Choi, Y. H., Choi, I. B., Won, Y. J., Yang, S. J. and Kim, Y. G. 2008. Haplotype diversity and durability of resistance genes to blast in Korean Japonica rice varieties. J. Crop Sci. Biotech. 11:205-214.

Cuong, N. M., Lang, T. and Buu, B. C. 2006. Applications of microsatellite and sequence tagged site marker to detect blast resistance in local rice (Oryza sativa L.). Hanoi: Nong Nghiep. $52-68 \mathrm{pp}$.

Das, A., Soubam, D., Singh, P. K., Thakur, S., Singh, N. K. and Sharma, T. R. 2012. A novel blast resistance gene, Pi54rh cloned from wild species of rice, Oryza rhizomatis confers broad spectrum resistance to Magnaporthe oryzae. Funct. Integr. Genomics 12:215-228.

Doyle, J. J. and Doyle, J. L. 1987. A rapid DNA isolation procedure for small quantities of fresh leaf tissue. Phytochem. Bull. 19:11-15.

Eizenga, G. C., Agrama, H. A., Lee, F. N., Yan, W. G. and Jia, Y. 2006. Identification of novel resistance genes in newly introduced blast resistance rice germplasm. Crop Sci. 46:18701878.

Fjellstrom, R., Mc-Clung, A. M. and Shank, A. R. 2006. SSR markers closely linked to the $P i-z$ locus are useful for selection of blast resistance in a broad array of rice germplasm. Mol. Breed. 17:149-157.

Fuentes, J. L., Correa-Victiria, F. J., Escobar, F., Prado, G., Aricapa, G., Duque, M. C. and Tohme, J. 2007. Identification of microsatellite markers linked to the blast resistance gene $P i$ $1(t)$ in rice. Euphytica 160:295-304.

Fukuoka, S., Saka, N., Koga, H., Ono, K., Shimizu, T., Ebana, K., Hayashi, N., Takahashi, A., Hirochika, H., Okuno, K. and Yano, M. 2009. Loss of function of a proline-containing protein confers durable disease resistance in rice. Science 325:998-1001.

Gu, K., Yang, B., Tian, D., Wu, L., Wang, D., Sreekala, C., Yang, F., Chu, Z., Wang, G. L., White, F. F. and Yin, Z. 2005. R gene expression induced by type-III effecter triggers disease resistance in rice. Nature 435:1122-1125.

Han, S. S., Ryu, J. D., Shim, H. S., Lee, S. W., Hong, Y. K. and Cha, K. H. 2001. Breakdown of resistant cultivars by new race $K I-1117 a$ and race distribution of rice blast fungus during 1999-2000 in Korea. Res. Plant Dis. 7:86-92.

Hayashi, K. and Yoshida, H. 2009. Refunctionalization of the ancient rice blast disease resistance gene Pit by the recruitment of a retrotransposon as a promoter. Plant J. 57:413-425.

Hayashi, K., Yoshida, H. and Ashikawa, I. 2006. Development of PCR-based allele specific and InDel marker sets for nine rice blast resistance genes. Theor. Appl. Genet. 113:251-260.

Hayashi, N., Inoue, H., Kato, T., Funao, T., Shirota, M., Shimizu, T., Kanamori, H., Yamane, H., Hayano-Saito, Y., Matsumoto, T., Yano, M. and Takatsuji, H. 2010. Durable panicle blastresistance gene $\mathrm{Pbl}$ encodes an atypical CC-NBS-LRR protein and was generated by acquiring a promoter through local genome duplication. Plant J. 64:498-510.

Hittalmani, S., Parco, T. A., Mew, T. V. and Zeigler, R. S. 2000. Fine mapping and DNA marker-assisted pyramiding of the three major genes for blast resistance in rice. Theor. Appl. Genet. 100:1121-1128.

Huang, H., Huang, L., Feng, G., Wang, S., Wang, Y., Liu, J., Jiang, N., Yan, W., Xu, L., Sun, P., Liu, Z., Pan, S., Liu, X., Xiao, Y., Liu, E., Dai, L. and Wang, G. 2010. Molecular mapping of the new blast resistance genes Pi47 and Pi48 in the durably resistant local rice cultivar Xiangzi 3150. Phytopathology 101:620-626.

Imam, J., Alam, S., Mandal, N. P., Variar, M. and Shukla, P. 2014. Molecular screening for identification of blast resistance genes in North East and Eastern Indian rice germplasm (Oryza sativa L.) with PCR based makers. Euphytica 196:199-211.

Jia, Y., Bryan, G. T., Farrall, L. and Valent, B. 2003. Natural variation at the Pi-ta rice blast resistance locus. Phytopathology 93:1452-1459.

Kim, J. S., Ahn, S. N., Kim, C. K. and Shim, C. K. 2010. Screening of rice blast resistance genes from aromatic rice germplasms with SNP markers. Plant Pathol. J. 26:70-79.

Lee, S. K., Song, M. Y., Seo, Y. S., Kim, H. K., Ko, S., Cao, P. J., Suh, J. P., Yi, G., Roh, J. H., Lee, S., An, G., Hahn, T. R., Wang, G. L., Ronald, P. and Jeon, J. S. 2009. Rice Pi5mediated resistance to Magnaporthe oryzae requires the presence of two coiled-coilnucleotide- binding-leucine-rich repeat genes. Genetics 181:1627-1638.

Li, Y. B., Wu, C. J., Jiang, G. H., Wang, L. Q. and He, Y. Q. 2007. Dynamic analyses of rice blast resistance for the assessment of genetic and environmental effects. Plant Breed. 126:541547.

Lin, F., Chen, S., Que, Z., Wang, L., Liu, X. and Pan, Q. 2007. The blast resistance gene Pi37 encodes a nucleotide binding siteleucine-rich repeat proteinand is a member of a resistance gene cluster on rice chromosome 1. Genetics 177:1871-1880.

Liu, B., Zhang, S. H., Zhu, X. Y., Yang, Q. Y., Wu, S. Z., Mei, M. T., Mauleon, R., Leach, J., Mew, T. and Leung, H. 2004. Cadidate defense genes as predictors of quantitative blast resistance in rice. Mol. Plant-Microbe Interact. 17:1146-1152.

Liu, J., Wang, X., Mitchell, T., Hu, Y., Liu, X., Dai, L. and Wang, G. L. 2010. Recent progress and understanding of the molecular mechanisms of the rice Magnaporthe oryzae interaction. Mol. Plant Pathol. 11:419-427.

Liu, X. Q., Wang, L., Chen, S., Lin, F. and Pan, Q. H. 2005. Genetic and physical mapping of Pi36(t), a novel rice blast resistance gene located on rice chromosome 8. Mol. Genet. Genomics 274:394-401.

Liu, X., Lin, F., Wang, L. and Pan, Q. 2007. The in silico map- 
based cloning of Pi36, a rice coiled-coil nucleotide-binding site leucine-rich repeat gene that confers race-specific resistance to the blast fungus. Genetics 176:2541-2549.

Mackill, D. J. and Bonman, J. M. 1992. Inheritance of blast resistance in near-isogenic lines of rice. Phytopathology 82:746749.

Okuyama, Y., Kanzaki, H., Abe, A., Yoshida, K., Tamiru, M., Saitoh, H., Fujibe, T., Matsumura, H., Shenton, M., Galam, D. C., Undan, J., Ito, A., Sone, T. and Terauchi, R. 2011. A multifaceted genomics approach allows the isolation of rice Pia blast resistance gene consisting of two adjacent NBS-LRR protein genes. Plant J. 66:467-479.

Qu, S., Liu, G., Zhou, B., Bellizzi, M., Zeng, L., Dai, L., Han, B. and Wang, G. L. 2006. The broad spectrum blast resistance gene $P i 9$ encodes a nucleotide-binding site leucine-rich repeat protein and is a member of a multigene family in rice. Genetics 172:1901-1914.

Roy-Chowdhury, M., Jia, Y., Jackson, A., Jia, M. H., Fjellstrom, R. and Cartwright, R. 2012a. Analysis of rice blast resistance gene $P i-z$ using pathogenicity assays and DNA markers. Euphytica 184:35-47.

Roy-Chowdhury, M., Jia, Y., Jia, M. H., Fjellstrom, B. and Cartwright, R. 2012b. Identification of the rice blast resistance gene $P i b$ in the national small grains collection. Phytopathology 102:700-706.

Shang, J., Tao, Y., Chen, X., Zou, Y., Lei, C., Wang, J., Li, X., Zhao, X., Zhang, M., Lu, Z., Xu, J., Cheng, Z., Wan, J. and $\mathrm{Zhu}, \mathrm{L} .2009$. Identification of a new rice blast resistance gene Pid 3 by genome-wide comparison of paired nucleotidebinding site-leucine-rich repeat genes and their pseudogene alleles between the two sequenced rice genomes. Genetics 182:1303-1311.

Sharma, T. R., Madhav, M. S., Singh, B. K., Shanker, P., Jana, T. K., Dalal, V., Pandit, A., Singh, A., Gaikwad, K., Upreti H. C. and Singh, N. K. 2005. High-resolution mapping, cloning and molecular characterization of the Pi-kh gene of rice, which confers resistance to Magnaporthe grisea. Mol. Genet. Genomics 274:569-578.

Sharma, T. R., Rai, A. K., Gupta, S. K., Vijayan, J., Devanna, B. N. and Ray, S. 2012. Rice blast management through host-plant resistance: retrospect and prospects. Agric. Res. 1:37-52.

Shikari, A. B., Khanna, A., Krishnan, S. G., Singh, U. D., Rathour, R., Tonapi, V., Sharma, T. R., Nagarajan, M., Prabhu, K. V. and Singh, A. K. 2013. Molecular analysis and phenotypic validation of blast resistance genes Pita and Pita2 in landraces of rice (Oryza sativa L.). Indian J. Genet. 73:131-141.

Takahashi, A., Hayashi, N., Miyao, A. and Hirochika, H. 2010. Unique features of the rice blast resistance Pish locus revealed by large scale retrotransposon-tagging. BMC Plant Biol. 10:175.

Tang, J., Zhu, X., Wang, Y., Liu, L., Xu, B., Li, F., Fang, J. and Chu, C. 2011. Semi-dominant mutations in the CC-NB-LRRtype R gene, NLS1, lead to constitutive activation of defense responses in rice. Plant J. 66:996-1007.

Tanksley, S. D. and Mc-Couch, S. R. 1997. Seeds banks and molecular maps: unlocking genetic potential from the wild. Science 277:1063-1066.

Valent, B. 1990. Rice blast as a model system for plant pathology. Phytopathology 80:33-36.

Variar, M., Vera, C. C. M., Carrillo, M. G., Bhatt, J. C. and Sangar, R. B. S. 2009. Rice blast in India and strategies to develop durably resistant cultivars. In: Xiaofan, W. and Valent, B. (eds). Advances in genetics, genomics and control of rice blast disease. Springer, New York, 359-374 pp.

Wang, C., Hirano, K. and Kawasaki, S. 2002. Cloning of Pita-2 in the centromeric region of chr-12 with HEGS: high efficiency genome scanning. Third International Rice Blast Conference. $25 \mathrm{p}$.

Wang, X., Fjellstrom, R. G., Jia, Y., Yan, W., Jia, M. H., Scheffer, B. E., Wu, D., Shu, Q. and Mc-Clung, A. M. 2010. Characterization of Pita blast resistance gene in an international rice core collection. Plant Breed. 129:491-501.

Wang, Z. X., Yano, M., Yamanouchi, U., Iwamoto, M., Monna, L., Hayasaka, H., Katayose, Y. and Sasaki, T. 1999. The Pib gene for rice blast resistance belongs to the nucleotide-binding and leucine-rich repeat class of plant disease resistance genes. Plant J. 19:55-64.

Xiao, W. M., Yang, Q. Y., Wang, H., Guo, T., Liu, Y. Z., Zhu, X. Y. and Chen, Z. Q. 2010. Identification and fine mapping of a resistance gene to Magnaporthe oryzae in a space-induced rice mutant. Mol. Breed. 28:303-312.

Yan, W., Rutger, J. N., Bockelman, H. E., Fjellstrom, R. G., Chen, M. H., Tai, T. and Mc-Clung, A. M. 2007. Development and evaluation of a core subset of the USDA rice (Oryza sativa L.) germplasm collection. Crop Sci. 47:869-878.

Yang, J. Y., Chen, S., Zeng, L. X., Li, Y. L., Chen, Z., Li, C. Y. and Zhu, X. Y. 2008. Race specificity of major rice blast resistance genes to Magnaporthe grisea isolates collected from indica rice in Guangdong. Rice Sci. 15:311-318.

Yuan, B., Zhai, C., Wang, W., Zeng, X., Xu, X., Hu, H., Lin, F., Wang, L. and Pan, Q. 2011. The Pik-p resistance to Magnaporthe oryzae in rice is mediated by a pair of closely linked CC-NBSLRR genes. Theor. Appl. Genet. 122:1017-1028.

Zhai, C., Lin, F., Dong, Z., He, X., Yuan, B., Zeng, X., Wang, L. and Pan, Q. 2011. The isolation and characterization of Pik, a rice blast resistance gene which emerged after rice domestication. New Phytol. 189:321-334.

Zhou, B., Qu, S., Liu, G., Dolan, M., Sakai, H., Lu, G., Bellizzi, M. and Wang, G. L. 2006. The eight amino-acid differences within three leucine-rich repeats between $P i 2$ and Piz- $t$ resistance proteins determine the resistance specificity to Magnaporthe grisea. Mol. Plant-Microbe Interact. 19:1216-1228.

Zhu, M., Wang, L. and Pan, Q. H. 2004. Identification and characterization of a new blast resistance gene located on rice chromosome 1 through linkage and differential analyses. Phytopathology 94:515-519. 